\title{
The XPD/ERCC2, RAD51 and hOGG1 Gene Polymorphisms in Turkish Patients with Advanced-Stage Gastric Cancer
}

\author{
İleri Evre Mide Kanserli Türk Hastalarda XPD/ERCC2, RAD51 ve \\ hOGG1 Gen Polimorfizmi
}

\author{
Ozgur TANRIVERDI ${ }^{1}$, Gamze GOKOZ DOGU ${ }^{2}$, Ayşegul KARGI ${ }^{3}$, Hakan AKCA ${ }^{4}$, Aydin DEMIRAY ${ }^{4}$, \\ Burcu YAPAR TASKOYLU ${ }^{2}$, Gokcen DEMIRAY ${ }^{2}$, Arzu YAREN ${ }^{2}$, Can OZLU ${ }^{5}$, Ahmet ERGIN ${ }^{6}$ \\ ${ }^{1}$ Muğla Sitkı Koçman University School of Medicine, Department of Medical Oncology, Muğla \\ ${ }^{2}$ Pamukkale University School of Medicine, Department of Internal Medicine, Division of Medical Oncology, Denizli \\ ${ }^{3}$ Medstar Hospital, Clinic of Medical Oncology, Antalya \\ ${ }^{4}$ Pamukkale University School of Medicine, Department of Medical Biology, Denizli \\ ${ }^{5}$ Denizli State Hospital, Department of Internal Medicine, Denizli \\ ${ }^{6}$ Pamukkale University School of Medicine, Department of Public Health, Denizli
}

\begin{abstract}
In this study, we evaluated the effects of XPD/ERCC2, RAD51 and hOGG1 gene polymorphisms on prognosis in Turkish patients with advanced gastric cancer. A total of 31 gastric cancer patients with locally inoperable or distant metastasis and performance status of 0-2 and 29 healthy volunteers as the control group were enrolled in this study. DNA was isolated from serum and then single nucleotide gene polymorphism analyses were done by MassARRAY Analyzer 4 System [Sequenom]. Statistical significance of the observed genotype frequencies was evaluated according to Hardy-Weinberg rule compared to the expected genotype frequencies. Median age was 68 years: $74 \%$ male, $26 \%$ female in the study group. We determined the XPD/ERCC2 Asp312Asn [rs1799793] single nucleotide gene polymorphism G23591A, RAD51 [rs1801320] single nucleotide gene polymorphism G135C and hOGG1 Ser 326 Cys [rs1052133] single nucleotide gene polymorphism. We could not find any significant association between the genotypes and prognosis in Turkish patients with gastric cancer.

Keywords: Gastric Cancer, Gene Polymorphism, Prognosis,
\end{abstract} Single Nucleotide Gene Polymorphism

\section{Introduction}

Epidemiological studies have suggested that gastric cancer is the fourth most common cancer and the second leading cause of cancer death worldwide. Incidence and mortality of gastric cancer have been decreasing in most countries, but almost two-thirds of new cases occurred in less developed countries (1). The difference in incidence between countries is

\begin{tabular}{ll}
\hline & ORCID No \\
Ozgur TANRIVERDI & $0000-0002-0598-7284$ \\
Gamze GOKOZ DOGU & $0000-0001-8142-0362$ \\
Ayşegul KARGI & $0000-0003-4797-7313$ \\
Hakan AKCA & $0000-0001-9138-0755$ \\
Aydin DEMIRAY & $0000-0002-3343-0184$ \\
$\begin{array}{l}\text { Burcu YAPAR TASKOYLU } \\
\text { Gokcen DEMIRAY }\end{array}$ & $0000-0003-4755-2753$ \\
$\begin{array}{l}\text { Arzu YAREN } \\
\text { Can OZLU }\end{array}$ & $0000-0003-4397-5468$ \\
Ahmet ERGIN & $0000-0002-9573-1177$ \\
$\begin{array}{l}\text { Başvuru Tarihi / Received: } \\
\text { Kabul Tarihi / Accepted : }\end{array}$ & 16.01.2020 \\
$\begin{array}{l}\text { Adres / Correspondence } \\
\text { Muğla Sitkı Koçman University School of Medicine, Department } \\
\text { of Oncology , Muğla } \\
\text { e-posta / e-mail }\end{array}$ & Ozgur TANRIVERDI \\
\hline & mugla.medicaloncology@gmail.c \\
\hline
\end{tabular}

\section{Oz}

Bu çalışmada ileri evre mide kanserli Türk hastalarda XPD/ERCC2, RAD51 ve hOGG1 gen polimorfizminin prognoz üzerine etkisinin olup olmadığını değerlendirdik. Çalışmaya performans durumu $0-2$ olan, inoperabl lokal ileri veya uzak metastazlı 31 mide kanseri hastası ile kontrol grubu olarak 29 sağlıklı birey dahil edildi. DNA serumdan izole edildikten sonra tek nükleotid gen polimorfizmi MassARRAY Analyzer 4 System [Sequenom] kullanılarak analiz edildi. Gözlenen genotip frekanslarının istatistiksel değeri beklenen genotip frekanslarına kıyasla Hardy-Weinberg kuralına göre belirlendi. Hasta grubunda ortanca yaş 68 (yıl) ve hastaların $\% 74$ 'ü erkek, \%26's1 kadın idi. XPD/ERCC2 Asp312Asn [rs1799793] tek nükleotit gen polimorfizmi G23591A, RAD51 [rs1801320] tek nükleotit gen polimorfizmi G135C ve hOGG1 Ser 326 Cys [rs1052133] tek nükleotid gen poliforfizmi tespit edildi. Mide kanserli Türk hastalarda genotipler ile prognoz arasında anlamlı bir ilişki kuramadık.

Anahtar Kelimeler: Gen Polimorfizmi, Mide Kanseri, Prognoz, Tek Nükleotid Gen Polimorfizmi assumed to be related to some environmental factors such as tobacco use, a diet poor in fruits and vegetables or rich in salt, and Helicobacter pylori infection (2,3). In addition to the above factors, genetic polymorphisms in the carcinogen detoxification, antioxidant protection, DNA repair and cell proliferation processes are also crucial in the development of gastric cancer. DNA damage is a very important process for cancer induction, promotion and progression (4-6). Genetic polymorphism describes the differences in both the coding and noncoding portions of DNA. Human single nucleotide polymorphisms (SNPs) have led to the identification of interesting SNP markers for some disorders such as cancer. There are five major DNA repair pathways: direct repair, base excision repair (BER), nucleotide excision repair (NER), mismatch repair, and double-strand break repair (DSBR) $(4,7)$.

Enzymes in BER (e.g. 8- oxoguanine DNA glycosylase [HOGG1], apurinic/apyrimidine endonuclease 1 [APE1], and X-ray repair cross complementing group 1 protein [XRCC1]), remove simple base modifications, such as single-strand breaks, non-bulky adducts, oxidative DNA damage, alkylation adducts and damage induced by ionizing 
radiation $(8,9)$. NER enzymes (e.g. XPD/ERCC2, $\mathrm{XPG/ERCC5)} \mathrm{remove} \mathrm{more} \mathrm{complex,} \mathrm{bulky} \mathrm{lesions,}$ often caused by environmental agents (e.g. polycyclic aromatic hydrocarbons and arylamines) or UV light and the repair of oxidative stress $(10,11)$.

RAD51 is a homolog of bacterial RecA protein, which is essential for maintaining genome stability and plays a central role in the homology-dependent recombination repair of the DNA double-strand breaks by assembling nucleoprotein filaments on single-stranded DNA and mediating strand invasion and exchange between the damaged site and homologous DNA (12). Genetic polymorphisms in the RAD51 gene may contribute to the development and progression of cancer (13).

There is intensive research focused on the association of DNA repair gene polymorphisms and development of gastric cancer. However, the contribution of genetic polymorphisms in DNA repair genes to gastric cancer risk is still not clarified.

We decided to evaluate our patients for 3 genetic SNPs. To the best of our knowledge, we didn't find any trial on prognosis of gastric cancer that researched XPD/ERCC2 Asp312Asn (rs1799793) single nucleotide gene polymorphism G23591A in the Turkish population.

The aim of this study was to determine whether XPD/ERCC2, RAD51 and hOGG1 gene polymorphisms were associated with an increased risk for gastric cancer.

\section{Material and Method}

A total of 31 gastric cancer patients with locally inoperable or distant metastasis and performance status of 0-2 and 29 healthy volunteers as the control group were enrolled in this study. The controls were randomly selected from volunteer blood donors and healthy individuals who applied to the check-up unit of the internal medicine outpatient clinic, which have similar age and sex features with the gastric cancer patients. Both the patients with gastric cancer and the individuals in the control group were of Turkish origin. However, those with a personal or family history of any cancer or chronic diseases such as cardiovascular or cerebrovascular disease, diabetes mellitus, hypertension, renal disease were excluded. The Ethics Committee of Pamukkale University approved the present study.

Five $\mathrm{ml}$ of peripheral blood was collected for the extraction of serum DNA before the administration of chemotherapy to the patients. Serum DNA was extracted and purified by using a QIAamp Blood Kit (Qiagen, Benelux, the Netherlands) according to the manufacturer's instructions with the following modifications. One column was used repeatedly until the whole sample had been processed, and the resulting DNA was eluted in $50 \mathrm{~mL}$ of sterile elution buffer. The concentration and purity of the extracted DNA were determined by spectrophotometry, and the extracted DNA was stored at $-20^{\circ} \mathrm{C}$ until use. PCR reactions were performed for each gene with 15 ng serum circular DNA by specific primers which are given below:

5'-

ACGTTGGATGTCGGGGCTCACCCTGASTRIC CANCERGASTRICCANCER-3' and 5'ACGTTGGATGACGGACGCCCACCTGGCCAA -3 ', for XPD;

5'-

ACGTTGGATGTGGGGASTRICCANCERAGCG AGTAGAGAA-3, and 5'ACGTTGGATGCGACCCGASTRIC CANCERCGGCCCCCA-3', for RAD51; 5'ACGTTGGATGTTTGCTGGTGGCTCCTGAG-3' and 5'ACGTTGGATGASTRICCANCERCACAGACTC CACCCTCC -3', for hOGG1.

The sequences of the primers used for sequenom were:

5'-

CCTGASTRICCANCERGASTRICCANCERCTT CGT-3', for XPD;

5'- GTGGAGCGTAAGCCA-3', for RAD51; and 5'- CTCCTGAGASTRICCANCERTGGCGG-3', for hOGG1.

The MassARRAY Analyzer 4 and SEQUENOM SEQUENOM Nano Dispenser (chip number G0710902 Sequnom MassARRAY 4) device was used for the detection of XPD/ERCC2, RAD51 and hOGG1 gene polymorphisms.

Student's t-test and the $\chi^{2}$-test were used to compare response rates according to genotype. All statistical analyses were performed using SPSS 17.0 and for statistical significance, $\mathrm{p}$ value was found to be $<0.05$. Statistical significance of the observed genotype frequencies was evaluated according to Hardy-Weinberg rule compared to the expected genotype frequencies. Hardy-Weinberg equilibrium was evaluated by the chi-square

\section{Results}

A total of 31 gastric cancer patients with locally inoperable or distant metastasis and performance status of 0-2 and 29 healthy control group volunteers were enrolled in this study. The mean age of patients with gastric cancer was 68 years (range: 41-90) and; $74 \%(n=23)$ were male. The mean age of the individuals in the control group was 62 years (range $=40-78)$ and $69 \%(n=20)$ were male. There weren't any significant differences between cases and controls in terms of gender and age $(p=0.218$ and $\mathrm{p}=0.275$, respectively). Table 1 showed the characteristics of gastric cancer patients.

Both the gastric cancer patients and control group volunteers were evaluated for the 
XPD/ERCC2, RAD51 and hOGG1 genotype and allele frequencies were analyzed.

Table 1. Characteristics of gastric cancer patients

\begin{tabular}{lll}
\hline Characteristics & $\mathbf{N}$ & $\mathbf{( \% )}$ \\
\hline Gender & 8 & 26 \\
Female & 23 & 74 \\
Male & & \\
ECOG PS & 12 & 39 \\
0 & 12 & 39 \\
1 & 7 & 22 \\
2 & & \\
Surgery & 29 & 19 \\
Yes & 2 & $81]$ \\
No & & \\
Stage at onset & 13 & 42 \\
III & 18 & {$[58$} \\
IV & & \\
Weight loss & 29 & 93 \\
Yes & 2 & 7 \\
No & & \\
Distant metastasis & 16 & 52 \\
Yes & 15 & 48 \\
No & & \\
Histology & 22 & 71 \\
Adenocarcinoma & 9 & 29 \\
Signet-ring cell carcinoma & & \\
Smoking status & 24 & 77 \\
Yes & 7 & 23 \\
No & & \\
\hline
\end{tabular}

Genotype and allele distributions of these polymorphisms were not statistically significant between patients and controls (Table 2). Moreover, the frequency of genotypes in these genes in patients did not show a significant deviation from HardyWeinberg equilibrium (for XPD/ERCC2 gene $\mathrm{x}^{2}=0.95, \mathrm{df}=1, \mathrm{p}=0.32$; for RAD51 gene $\mathrm{x}^{2}=2.126$, $\mathrm{df}=1, \mathrm{p}=0.1448$; for HOGG1 $\mathrm{x}^{2}=0.593, \mathrm{df}=1$, $\mathrm{p}=0.4413$ ).

We determined the XPD/ERCC2 Asp312Asn (rs1799793) single nucleotide gene polymorphism G23591A, RAD51 (rs1801320) single nucleotide gene polymorphism G135C and hOGG1 Ser 326 Cys (rs1052133) single nucleotide gene polymorphism.

We found XPD/ERCC2 gene GA, GG, AA genotype and $\mathrm{A}, \mathrm{G}$ allele frequencies in gastric cancer patients as $54.8 \%, 35.5 \%, 9.7 \%$ and $37.1 \%$, $62.9 \%$, respectively. The patients with GA genotype had a longer survival $(11.96 \pm 2.177$ months, $95 \%$ CI 7.69-16.23) than the other genotypes. However, this difference is not statistically significant $(\mathrm{p}=0.448)$.

We found that RAD51 gene GG, CG, CC genotype and $\mathrm{G}, \mathrm{C}$ allele frequencies as $83.9 \%$, $12.9 \%, 3.2 \%, 90.3 \%, 9.7 \%$, respectively; for hOGG1 gene GC, CC, GG genotype and C, G allele frequencies as $48.4 \%, 45.2 \%, 6.5 \%, 69.4 \%, 30.6 \%$, respectively. None of the evaluated polymorphisms were associated with the prognosis of gastric cancer.

\section{Discussion}

Devastating factors in DNA, including damaging factors and replication defects, can lead to serious consequences for the organism in its life time. For the continuation of a healthy life, it is necessary to repair DNA to remove damage and reduce the number of mutations. The human body uses natural processes to repair for DNA, which include the direct damage reverse repair pathway, base excision, nucleotide excision, mismatch repair, and recombination repair $(4,7)$. Changes in the protein encoding genes, including DNA repair genes, can lead to increased numbers of mutations, cancer development and inherited diseases.

Table 2. Genotype and allele frequencies for DNA repair genes in gastric cancer patients

\begin{tabular}{lccccc}
\hline $\begin{array}{l}\text { Genotype/ } \\
\text { Alleles }\end{array}$ & $\begin{array}{c}\text { Patient } \\
\mathbf{n}\end{array}$ & $\begin{array}{c}\text { Patient } \\
\mathbf{\%}\end{array}$ & $\begin{array}{c}\text { Control } \\
\mathbf{n}\end{array}$ & $\begin{array}{c}\text { Control } \\
\mathbf{\%}\end{array}$ & $\begin{array}{c}\text { P } \\
\text { value }\end{array}$ \\
\hline XPD /ERCC2 & Asp312Asn & {$[\mathrm{rs} 1799793]$} & & & \\
GG & 11 & 35.5 & 10 & 35 & \\
GA & 17 & 54.8 & 14 & 48 & \\
AA & 3 & 9.7 & 5 & 17 & 0.68 \\
G & 39 & 62.9 & 34 & 58.6 & \\
A & 23 & 37.1 & 24 & 41.4 & 0.631 \\
RAD51 & {$[\mathrm{rs} 1801320]$} & & & & \\
GG & 26 & 83.9 & 26 & 89.7 & \\
GC & 4 & 12.9 & 3 & 10.3 & \\
CC & 1 & 3.2 & - & - & 0.939 \\
G & 56 & 90.3 & 55 & 94.8 & \\
C & 6 & 9.7 & 3 & 5.2 & 0.349 \\
HOGG1 [rs1052133] & & & & \\
CC & 14 & 45.2 & 14 & 48.3 & \\
GC & 15 & 48.4 & 12 & 41.4 & \\
GG & 2 & 6.5 & 3 & 10.3 & 0.792 \\
C & 43 & 69.4 & 40 & 69.0 & \\
G & 19 & 30.6 & 18 & 31.0 & 0.963 \\
\hline
\end{tabular}

In studies investigating the association between gastric cancer and XPD/ERCC2 Asp312Asn [rs1799793] G23591A, RAD51 [rs1801320] G135C, and hOGG1 Ser 326 Cys [rs1052133] single nucleotide gene polymorphisms in different ethnic groups, incompatible results were detected $(4,14$ 19). However, there is no study in the literature for gastric cancer prognosis and XPD/ERCC2 Asp312Asn [rs1799793] G23591A and RAD51 [rs1801320] G135C polymorphisms in the Turkish population.

Among these genes, the most investigated gene is HOGG1. Our result indicated no significant difference between Ser326Cys HOGG1 polymorphism and the incidence of gastric cancer in comparison with the control group as well as the prognosis of gastric cancer that is in agreement with those found in Polish, Japanese, Brazilian, Spanish, Turkish populations $(4,14-20)$. Some studies didn't show any correlation between gastric cancer and Ser326Cys HOGG1 polymorphism in the Turkish population $(4,10,13)$. The lack of association between the HOGG1 gene polymorphism and the gastric cancer incidence are consistent in these different ethnic study groups, suggesting that environmental factors are not in play. On the other hand, it was reported that some individual differences, such as drinking and nutritional habits, might alter the association between HOGG1 polymorphism and the development of gastric 
cancer (21). We didn't investigate individual differences in patients and control group regarding with HOGG1 polymorphism. Maybe this information would give us some important data.

The RAD51 gene is an orthologue of Escherichia coli RecA, and the gene product Rad51 protein plays a central role in the homologous recombination [HRR] (22,23). RAD51 roles including strand invasion, polymerizing onto a DNA end and mediating the transfer and nucleoprotein filament to a complementary homologous strand on the intact DNA. Functional implications of G135C polymorphism of the RAD51 gene polymorphism are not known. But some researchers point out that it could affect mRNA stability or translational efficiency, leading to altered polypeptide product levels and altering the function of the RAD51 protein (17). Our result indicated no association between RAD51 [rs1801320] G135C polymorphism and the gastric cancer incidence when compared with the control group. To the best of our knowledge, we didn't find any study in the Turkish population for this gene polymorphism.

Bulky DNA adducts are repaired by nucleotide excision repair [NER] pathway. NER is capable of removing helix-distorting base lesions produced by ultraviolet light [UV] and an array of chemical agents. XPD is believed to participate in DNA unwinding during NER and transcription because it possesses single-strand DNA-dependent ATPase and DNA helicase activities (14,19). Single nucleotide polymorphism in XPD in codon 751 is related with altered repair capacity (24). Thus, Engin at al. (14) studied that single nucleotide polymorphism in XPD in codon 751. They didn't find any association with XPD Lys751Gln. We focused on other polymorphisms of XPD gene. For Asian population, control groups showed that Asp/Asp GG genotype is more frequent than the others. Nevertheless, for the gastric cancer patients, we found conflicting results in the Asian population. Caucasian people show Asp/Asn GA genotype in some studies, but there are contradictory results in the literature. In our population, both control and patient groups, we found the most frequent genotype is GA. Our normal population is similar to Caucasians. Turkish gastric cancer patients are similar to both Caucasian and Asian genotypes, because some Asian studies showed that gastric cancer patient genotype is GA, but some Asian studies showed that gastric cancer patient genotype is $\operatorname{GG}(19,25,26)$. Xue et al.'s meta-analysis showed that XPD Gln751Gln [CC] genotype and Asn312Asn [AA] genotypes may seem to be more susceptible to gastric cancer in Asian populations but not in Caucasian populations, suggesting that the two genotypes may be important biomarkers of gastric cancer susceptibility for Asian populations (19). We didn't find any previous study of XPD Asp312Asn genetic polymorphism for the Turkish population. Our study showed that there is no association between XPD Asp312Asn genetic polymorphism and gastric cancer incidence in the Turkish patients.

\section{Limitations of the study and conclusion}

This is the first study to investigate the polymorphism of XPD/ERCC2, RAD51 and hOGG1 gene in Turkish patients with advanced gastric cancer, but there are some limitations. The first limitation is that the study involves a small number of patients, and this may have been a problem for statistical significance. The second limitation is that the patients included in the study do not receive targeted treatment because they cover a period of absence of some of the molecular advances in oncology due to the dates of treatment. The third limitation is that it has a heterogeneous treatment group because it is a retrospective study. Nevertheless, to shed light on the molecular studies of polymorphisms in genes associated with the advanced gastric cancer patients in Turkey, the preliminary results were obtained.

In conclusion, we didn't find any correlation between genetic polymorphism and increased risk in the advanced stage disease.

Ethics committee approval: Pamukkale University School of Medicine, Clinical Researches Ethics Comission, dated on 29.09.2010 and numbered B.30.2.PAÜ.0.01.00.00.400-3/65.

\section{References}

1. Siegel RL, Miller KD, Jemal A. Cancer statistics, 2020. CA Cancer J Clin. 2020;70(1):7-30.

2. Chow WH, Swanson CA, Lissowska J, et al. Risk of stomach cancer in relation to consumption of cigarettes, alcohol, tea and coffee in Warsaw, Poland. Int J Cancer. 1999;81(6):8716.

3. Stadtlander CT, Waterbor JW. Molecular epidemiology, pathogenesis and prevention of gastric cancer. Carcinogenesis. 1999;20(12):2195-208.

4. Canbay E, Agachan B, Gulluoglu M, et al. Possible associations of APE1 polymorphism with susceptibility and HOGG1 polymorphism with prognosis in gastric cancer. Anticancer Res. 2010;30(4):1359-64.

5. González CA, Sala N, Capellá G. Genetic susceptibility and gastric cancer risk. Int J Cancer. 2002;100(3):249-60.

6. Yasui W, Oue N, Kitadai Y, et al. Recent advances in molecular pathobiology of gastric carcinoma. In: The Diversity of Gastric Carcinoma. Kaminishi M, Takubo K, Mafune K [eds]. Tokyo Springer-Verlag, pp. 51-71, 2005.

7. Wood RD, Mitchell M, Sgouros J, et al. Human DNA repair genes. Science. 2001;291(5507):1284-9.

8. Oliver FJ, Menissier-de Murcia J, de Murcia G. Poly [ADPribose] polymerase in the cellular response to DNA damage, apoptosis, and disease. Am J Hum Genet. 1999;64(5):12828 .

9. Thompson LH, Schild D. Homologous recombinational repair of DNA ensures mammalian chromosome stability. Mutat Res. 2001;477(1-2):131-53.

10. Neumann AS, Sturgis EM, Wei Q. Nucleotide excision repair as a marker for susceptibility to tobacco-related cancers: a review of molecular epidemiological studies. Mol Carcinog. 2005;42(2):65-92. 
11. Sancar A, Tang MS. Nucleotide excision repair. Photochem Photobiol. 1993;57(5):905-21.

12. Kuznetsov SG, Haines DC, Martin BK, et al. Loss of Rad51c leads to embryonic lethality and modulation of Trp53dependent tumorigenesis in mice. Cancer Res. 2009;69(3):863-72.

13. Thacker J. The RAD51 gene family, genetic instability and cancer. Cancer Lett. 2005;219(2):125-35.

14. Engin AB, Karahalil B, Engin A, et al. DNA repair enzyme polymorphisms and oxidative stress in a Turkish population with gastric carcinoma. Mol Biol Rep. 2011;38(8):5379-86.

15. Hanaoka T, Sugimura H, Nagura K, et al. hOGG1 exon7 polymorphism and gastric cancer in case-control studies of Japanese Brazilians and non-Japanese Brazilians. Cancer Lett. 2001;170(1):53-61.

16. Li BR, Zhou GW, Bian Q, et al. Lack of association between the hOGG1 Ser326Cys polymorphism and gastric cancer risk: a meta-analysis. Asian Pac $J$ Cancer Prev. 2012;13(4):1145-9.

17. Poplawski T, Arabski M, Kozirowska D, et al. DNA damage and repair in gastric cancer-a correlation with the hOGG1 and RAD51 genes polymorphisms. Mutat Res. 2006;601(1-2):8391.

18. Tsukino H, Hanaoka T, Otani T, et al. hOGG1 Ser326Cys polymorphism, interaction with environmental exposures, and gastric cancer risk in Japanese populations. Cancer Sci. 2004;95(12):977-83.
19. Xue H, Lu Y, Lin B, et al. The effect of XPD/ERCC2 polymorphisms on gastric cancer risk among different ethnicities: a systematic review and meta-analysis. PLoS One. 2012;7:e43431.

20. Capellá G, Pera G, Sala N, et al. DNA repair polymorphisms and the risk of stomach adenocarcinoma and severe chronic gastritis in the EPIC-EURGAST study. Int $\mathrm{J}$ Epidemiol. 2008;37(6):1316-25.

21. Takezaki T, Gao CM, Wu JZ, et al. hOGG1 Ser [326]Cys polymorphism and modification by environmental factors of stomach cancer risk in Chinese. Int J Cancer. 2002;99(4):6247 .

22. Kawabata M, Kawabata T, Nishibori M. Role of recA/RAD51 family proteins in mammals. Acta Med Okayama. 2005;59(1):1-9.

23. Thompson LH, West MG. XRCC1 keeps DNA from getting stranded. Mutat Res. 2000;459(1):1-18.

24. Lunn RM., Helzlsouer KJ, Parshad R, et al. XPD polymorphisms: effects on DNA repair proficiency. Carcinogenesis. 2000;21(4):551-5

25. Chen Z, Zhang $\mathrm{C}, \mathrm{Xu} \mathrm{C}$, et al. Effects of selected genetic polymorphisms in xeroderma pigmentosum complementary group D on gastric cancer. Mol Biol Rep. 2011;38(3):150713.

26. Yuan T, Deng S, Chen M, et al. Association of DNA repair gene XRCC1 and XPD polymorphisms with genetic susceptibility to gastric cancer in a Chinese population. Cancer Epidemiol. 2011;35(2):170-4. 